\title{
Safety assessment of Czech motorways and national roads
}

\author{
Jiři Ambros ${ }^{*} \mathbb{D}$, Richard Turek, Milan Brich and Jan Kubeček
}

\begin{abstract}
Purpose: Czech motorways and national roads form the primary road network, which is critical in terms of safety. To be able to rationally manage network safety in both planning and operation stages, quality network-wide data and tools are needed. While such tools already exist in some countries, their transferability is limited. Authors therefore collected data and used it to develop tools, which allowed conducting state-of-the-art road safety impact assessment and network safety ranking in the Czech conditions. In addition to primary road network, focus was widened to include also secondary roads, in order to enable assessment of impacts on adjacent road network.

Methods: Accident, road and traffic data was collected, using not only existing databases, but also including own collection of traffic volumes on motorway interchanges. Data was used to develop the tools, based on accident prediction models and accident modification factors.

Results: The final accident prediction models and accident modification factors enabled conducting road safety impact assessment, for which simple on-line tool was also developed. For network safety ranking, accident prediction models were applied according to the Empirical Bayes method, in order to determine potential for safety improvement of the studied road network elements, with the final priority list visualized in an on-line map. Both outputs are shortly presented in the paper.

Conclusions: Data and sample size limitations lead to some compromises in modelling, such as using fixed proportions of observed accident severities or omitted variables. Nevertheless, the study established the practical framework for both road safety impact assessment and network safety ranking. It may serve as an example for other member countries, which also lack their local tools. Follow-up studies may focus on future model updating and improvements, as well as development of local accident modification factors.
\end{abstract}

Keywords: Road safety, Primary road network, Impact assessment, Network safety ranking

\section{Introduction}

Czech motorways and national roads constitute the primary road network. As one of the densest road networks in Europe, it carries the highest portion of traffic and connects the most important destinations in the Czech Republic [70]. This is challenging in terms of ensuring sufficient operation and maintenance, as well as safety, especially when the oldest part of motorway network is currently undergoing a large-scale renovation. For Czech national road agency, to be able to rationally manage network safety in both planning and operation stages, quality network-wide data and tools are needed. While such tools already exist in some countries, their

\footnotetext{
*Correspondence: jiri.ambros@cdv.cz

CDV - Transport Research Centre, Lišeňská 33a, 63600 Brno, Czech Republic
}

transferability is limited. This motivated authors to develop the tools for the Czech conditions.

The paper describes the process of developing accident prediction models for all types of Czech road network elements. Unlike a number of international studies, which usually dealt only with a selected road category, the study focused on the whole network in its complexity, covering motorways and national roads, and including road sections, intersections and interchanges. The authors conducted their own traffic survey, collected and processed all necessary data, and transformed the results into practical on-line tools. The developed tools are able to improve the effectiveness of road safety impact assessment (in the planning stage), as well as network safety ranking 
(identification of hazardous road locations in the operation stage).

Next Section 2 presents Literature review, followed by Data and methods (Section 3), Modelling, results and applications (Section 4) and concluded by Summary, discussion and conclusions.

\section{Literature review}

In recent years, European Union (EU) road safety orientation has been steered by EU Directive 2008/96/EC on road infrastructure safety management. Its main purpose is to establish management procedures to ensure safe road network, both in planning and operation stages. The Directive introduces four procedures: (1) road safety impact assessments and (2) road safety audits to be carried out for new road constructions or reconstructions; for existing roads, (3) network safety ranking to find the critical sections and (4) road safety inspections are to be periodically conducted. Two of these procedures - road safety impact assessment and network safety ranking - are further referred to in the text.

\subsection{Road safety impact assessment}

The idea of road safety impact assessment (RSIA) is that road safety should play an important role in the decision making during the design/planning stage [32, 50, 91]. The 2008 Directive defines RSIA as "a strategic comparative analysis of the impact of a new road or a substantial modification to the existing network on the safety performance of the road network", conducted alongside with other impact assessments, such as environmental impact assessment (EIA). By 2011, EU member states implemented the Directive procedures, including RSIA, to their national guidelines. However, independent analysis [79] concluded that in most cases, implementation only resulted in legislative documents, which offer mere Directive translations, rather than detailed guidelines for practical use. This is also probably a reason why RSIA remains the least used of Directive processes [79].

In principle, RSIA process involves definition and comparison of project variants ("do nothing" and one or more alternative scenarios), of which road safety performance needs to be assessed, including impacts on adjacent road network. Therefore, the underlying principle is quantification of safety. For this purpose, rates derived from accidents and injuries have been traditionally used, based on Police accident records and tabulated for several road network categories. This approach has been used in majority of European countries [12, 14, 19, 33, 36, 53, 85, 87]. However, in recent years, general use of accident rates is declining, since they were found to incorrectly assume a linear relationship between accident frequency and the degree of exposure [31, 41, 66]. Accident prediction models (APMs, or safety performance functions, SPFs) are instead preferred, since they are able to model accident frequency non-linearity, while also taking into account multiple explanatory variables (potential risk factors).

Another element of state-of-the-art approach to safety estimation involves accident modification factors (AMFs, also known as crash modification factors, CMFs). These are multiplicative factors, used for calculating the expected number of accidents after implementing safety measure at a specific site, through multiplication with expected accident frequency without treatment [38]. An AMF value higher than 1.0 indicates an expected increase in accidents, while a value lower than 1.0 indicates an expected reduction in accidents after the treatment. Various methodologies may be used in order to obtain AMF values, while before-after methodology with Empirical Bayes adjustment, has been deemed the most suitable [42, $64,74]$. In addition, AMFs were recently put into the centre of evidence-based decision-making [92], as a foundation of efficiency assessments to be applied in all cases, where "lack of reliable knowledge of the effects of countermeasures is a key barrier to the advancement of many critical, life-saving initiatives" [59].

To sum up, road safety impact assessment should be based on state-of-the-art assessment approach, using accident prediction models (APMs) and accident modification factors (AMFs). These elements constitute the foundations of evidence-based road safety management $[28,45,96]$. However, most of existing APMs and AMFs were developed in North America, Australasia or North-Western Europe [95], and it is known that these results may not be easily transferable $[40,59]$. This means that should state-of-the-art approach be applied, a number of EU member states, including the Czech Republic, need to develop their own tools. [9]

In Europe, APMs and AMFs are used for example in Denmark, Sweden and Finland [62, 82, 88]. Analysis of their guidelines and manuals showed that:

1. Applied models are relatively simple, developed for specific road types and intersection types and often involving only traffic volume. This practice is consistent with pilot Czech applications, where simple models were also found to provide sufficient quality of safety estimates $[4,6,11]$.

2. Accident modification factor sets are usually combined from local estimates and international sources, mainly the Norwegian Handbook of Road Safety Measures [31]. While this practice may be sufficient for relatively similar conditions of Sweden and Finland, suitability in the Czech Republic is uncertain.

\subsection{Network safety ranking}

The Directive states, that "safety ranking and management of the road network in operation" (in short, 
network safety ranking, NSR) should take into account the number of accidents, that have occurred in previous years per unit of road length in relation to the volume of traffic; and it should result in a priority list of road sections where an improvement of the infrastructure is expected to be highly effective. However, this description is rather short and thus provides, as well as RSIA description in the previous subsection, space for users in EU countries to apply their own approaches.

Several reviews indicated that in most countries, it is common to rely on traditional approaches, based on exceeding a fixed threshold of number of Police-reported accidents, without considering traffic volume and other risk factors $[22,30,37,52]$. Such definitions have also been applied in the Czech Republic [12, 86]. However, the research has shown that safety performance is influenced not only by accident occurrence, but also by its random variations, known as regression to the mean [42]. Due to this effect, the locations (road sections or intersections) identified as critical in one period, may not be critical in another period. The effect of these random fluctuations around a long-term mean may be corrected for by adding information on safety of similar units. The previously mentioned Empirical Bayes (EB) method, i.e. combination of the information contained in accident counts with the information contained in knowing the safety of similar entities, through using an accident prediction model, is considered a state-of-the-art method of road safety assessment [30, 44, $56]$. With the EB approach, in the end the list is produced which enables ranking the locations based on their potential for safety improvement [1]. The list includes not only accident locations, but also potentially hazardous locations, where no accidents have yet occurred.

Nevertheless, to be able to apply the EB method on a primary road network, it is necessary to develop a set of accident prediction models for all types of network elements (road sections, intersections, interchanges, etc.). For example, US Highway Safety Manual (HSM) introduced a number of US-specific accident prediction models. It was found that these models are well transferable between the US states [21, 76, 94]; however, transferability outside of the US was not always successful, as indicated by studies in Canada or Italy $[65,71,97]$. In the USA, also interchange safety analysis tools are available $[20,80]$. But like with HSM transferability, calibration of these tools may be uncertain [25, 81]. At the same time, several European countries have developed their own accident prediction models. However, they differ in their level of complexity: sometimes they are rather accident rates (i.e., implying linear relationship between traffic volume AADT and accidents) and they often consider either sections or intersections only [47, $62,82]$. In terms of data requirements, motorways can be even more challenging due to complexity of interchanges. This is probably why motorway safety studies usually omit interchanges or consider them part of sections [24, 27, 55, 73, 98].

Based on data from several European countries, a recent PRACT project has developed the base model to be calibrated to local conditions based on historical data [49]; limitation is that the models do not consider intersections, and the calibration tool is not yet available.

Following the international research, EB method with accident prediction model was recently applied in a part of Czech secondary road network [6]. However, its application in more complex primary road network has not yet been attempted.

\subsection{Summary}

The literature review, focusing on international stateof-the-art practice of road safety impact assessment (RSIA) and network safety ranking (NSR), concluded that both procedures should ideally be based on accident prediction models (in addition, RSIA also requires accident modification factors). The process of developing accident prediction models (APMs) has been known from several international studies and applications; however, these usually did not cover complete road networks. In the example of motorways, the models need to consider all the elements, including road sections, various types of intersections, interchanges, etc. How this was done in case of Czech primary roads (motorways and national roads), is described in the present paper.

\section{Data and methods}

In order to develop accident prediction models, as the main tool for both road safety impact assessment (RSIA) and network safety ranking (NSR), following points need to be resolved:

1. Sample definition

2. Network segmentation

3. Definition of variables

4. Selection of model function form

These steps are described in the following sections.

\subsection{Sample definition}

Since the idea of network safety ranking is to screen the entire road network, the sample should in theory comprise the whole population. However, the studied elements should be described by predictors, of which values are constant through the studied period. On the other hand, for the purpose of road safety impact assessment, accident prediction models may be based on a representative sample only.

Based on these requirements, following decision guided the definition of the studied samples:

- The parts of motorway network under renovation (including also the main motorway D1 between two 
largest cities Prague and Brno) were removed from the sample.

- The categories covered typical cross-sections, such as undivided/divided sections or 3-leg/4-leg intersections. Less frequent categories were omitted.

\subsection{Network segmentation}

Given the variety of Czech primary road network types, it was decided to distinguish motorways and national roads, as well as intersections (interchanges on motorways) and sections. Since RSIA also assesses impacts on adjacent road network, in addition to motorways and national roads, secondary roads were considered as well. At the same time, it was found that some categories were relatively rare: for example, 6-lane or $2+1$ sections are not as frequent, as would be required for developing a reliable accident prediction model. The same held for secondary roads, sample size of which was limited by unavailability of AADT data.

The final 11 categories were the following:

- Motorways

Interchanges (comprising conflict points and ramps)

$\bigcirc$ Sections (divided)

- National roads

Intersections (3-leg, 4-leg or roundabouts)

Sections (undivided or divided)

- Secondary roads

Intersections (3-leg or 4-leg)

Sections

In Table 1, the models are labelled as M01, M02, ..., M11. Regarding road sections, it is necessary to realize the consequences of various section lengths. In case of using homogeneity principle, i.e. keeping constant values of explanatory variables within a section, one may obtain too short sections [67]. In addition, for network ranking, it should be kept in mind that the follow-up on-site visits require manageable lengths (say, in units of kilometres). Therefore, the goal was to define logical section, while also trying to minimize differences within the sections.
On motorways, average length of sections between interchanges was $5 \mathrm{~km}$. These sections were thus taken as motorway sections. Subsequently, each interchange was split into conflict points (merging, diverging, crossing, etc.) and sections between them (ramps). On national roads, sections were defined in following steps:

1. Intersections with complete AADT data (on both major and minor roads) were identified. Sections were defined between these intersections, usually between two settlements.

2. In case of sections over $10 \mathrm{~km}$, some of intermediate intersections (even with incomplete AADT data) were used to split the sections into two.

Note that data contained both divided and undivided roads. On divided sections, sections in two directions were defined independently. Undivided sections comprised both directions.

\subsection{Definition of variables}

To develop accident prediction models, three basic datasets were needed (accident data, traffic data, road data), which will be described in the following paragraphs.

\subsubsection{Accident data}

Geo-located accidents have been collected by Czech Traffic Police since 2007, which makes it a suitable network-wide data source. However, this data is not routinely linked to the units of interest, for example interchange conflict points and ramps. Thus for this study, the linkage was done manually in GIS environment. Unfortunately, location precision was to some extent limited, and did not allow for example distinguishing accidents in acceleration/deceleration lanes or merging zones. Therefore, instead of using them to develop separate models, they were considered a subset of road section accidents.

Typically, 3-year period of accident data is used [30]. However, since motorways have relatively low accident frequencies, 7 years of accident data (2009-2015) were used in the study.

Table 1 Overview of categorization into 11 road network element types

\begin{tabular}{|c|c|c|c|c|c|c|c|c|c|c|}
\hline \multicolumn{3}{|c|}{ Motorways } & \multicolumn{5}{|c|}{ National roads } & \multicolumn{3}{|c|}{ Secondary roads } \\
\hline \multicolumn{2}{|c|}{ Interchanges } & \multirow[b]{2}{*}{ Sections } & \multicolumn{3}{|c|}{ Intersections } & \multicolumn{2}{|c|}{ Sections } & \multicolumn{2}{|c|}{ Intersections } & \multirow[b]{2}{*}{ Sections } \\
\hline $\begin{array}{c}\text { Conflict } \\
\text { points }\end{array}$ & Ramps & & 3-leg & 4-leg & $\begin{array}{l}\text { Round- } \\
\text { abouts }\end{array}$ & Undivided & Divided & 3-leg & 4-leg & \\
\hline M01 & M02 & M03 & M04 & M05 & M06 & M07 & M08 & M09 & M10 & M11 \\
\hline & & ... ne & ry for & ork sa & rankir & & & & & \\
\hline
\end{tabular}


In RSIA, modelling outputs (estimated accident frequencies) are to be further converted to accident costs and used in economic valuation of contemplated project variants. In this context, the models should be aligned with categories, used in Czech accident cost guidelines [90]. Thus, following accident variables were defined:

- number of accidents, which involved a fatality (FAT)

- number of accidents, which involved a severe injury (SEV)

- number of accidents, which involved a slight injury (SLI)

- number of accidents, which involved only property damage (PDO)

- including combinations, such as injury accidents $(\mathrm{FAT}+\mathrm{SEV}+\mathrm{SLI})$ and total accidents $(\mathrm{FAT}+\mathrm{SEV}+$ $\mathrm{SLI}+\mathrm{PDO})$

Accidents were split between sections and intersections based on their distance from intersections. Following Avelar et al. [13], all accidents within 100-m area around the intersection centre were considered intersection accidents.

\subsubsection{Traffic data}

Regarding traffic data, Czech national traffic census covers most of the primary road network; however, it was observed that it does not include interchange ramps on motorways. Since this data is required for developing interchange models, manual traffic counts needed to be performed on all ramps of approx. 450 interchanges (in more than 1000 profiles). Each profile was observed for $2 \mathrm{~h}$ of a working day and the results were factored up to AADT, using national guidelines [16].

Also on national roads, national traffic census data was found incomplete. AADT was missing on large number of minor roads, which intersect national roads - therefore it would not be possible to develop intersection models. Due to immense number of these intersections, it was not feasible to complement it with own survey. Therefore, simplified approach was taken, similar to the Norwegian practice [47] - i.e., not considering intersections with minor roads as individual units, but in terms of their frequency. Feasibility of this approach was previously tested in Czech conditions and found satisfactory [11].

\subsubsection{Road data}

Road data is digitally maintained by Road and Motorway Directorate's Road Databank and updated twice a year. This data was imported to authors' own GIS environment and used to obtain selected road parameters.
Additional information was collected manually from public online maps Mapy.cz or Google Maps.

Selection of specific explanatory variables (risk factors) should be guided by a theory, or previously documented evidence. Literature review indicated following typically used road-related variables:

- on interchanges: horizontal alignment, ramp type (on/off), ramp length, area type (rural/urban), etc. [17, 35, 51, 78, 83]

- on road sections: geometric characteristics (alignment), cross-section parameters (lane, median and shoulder widths), roadside hazard rating, speedrelated variables, pavement quality $[2,6,23,39,55]$

- on at-grade intersections: number of legs, lanes, turn lanes, type of traffic control device (signalized/ unsignalized), intersection angle, sight distance, etc. $[15,18,60,93]$

Based on the review, the following road-related explanatory variables were defined in this study:

- Interchange conflict points were described by their type, traffic control device, presence/absence of channelization by road marking, and the number of driving directions. Interchange ramps were described by their length, type, curvature and radius.

- For intersections on national roads, traffic control device and presence/absence of turn lanes and bypass lanes was recorded. Following previous Czech studies $[3,77]$, roundabouts were further described by number of legs, inscribed circle diameter, central island diameter, average of roundabout entry angles, average of deviation angles, width of circulatory lane, and width of truck apron.

- Sections of national roads were described by length and curvature change rate (CCR). In order to consider minor intersections, their number was used; analogically, number of accesses from petrol stations or rest areas was used on motorways. Both variables were used to calculate density (frequency per $1 \mathrm{~km}$ ). In addition, number of available parking space was used as a proxy for potential traffic flow to/from motorway rest areas.

Motorway network is located primarily outside of urban areas. Intersections on national roads were labelled according to their rural/urban location. Road sections, which comprised mix of both conditions, were described by a ratio of location in urban areas (e.g., 0.3 meaning $30 \%$ and $70 \%$ of length in urban and rural area, respectively). The list of explanatory variables, including their symbol, unit and data source, is provided in Table 2. 
Table 2 List of explanatory variables, with their symbol, unit and data source

\begin{tabular}{|c|c|c|c|}
\hline Element type & Symbol & Variable [unit] & Data source ${ }^{a}$ \\
\hline \multirow[t]{5}{*}{ Interchange conflict points } & AADT & Annual average daily traffic [veh/day] & NTC + own survey \\
\hline & Type & Type of conflict point (merging, diverging, etc.) & online maps \\
\hline & Signal & Traffic control device (unsignalized/signalized) & online maps \\
\hline & Channel & Channelization by road marking (no/yes) & online maps \\
\hline & Directions & Number of driving directions & online maps \\
\hline \multirow[t]{5}{*}{ Interchange ramps } & AADT & Annual average daily traffic [veh/day] & NTC + own survey \\
\hline & L & Length $[\mathrm{m}]$ & RMD \\
\hline & Ramp & Type (on-ramp, off-ramp, etc.) & online maps \\
\hline & Curve & Horizontal curvature (straight/curved) & own GIS \\
\hline & $R$ & Horizontal radius [m] & own GIS \\
\hline \multirow[t]{4}{*}{ Sections between interchanges } & AADT & Annual average daily traffic [veh/day] & NTC \\
\hline & L & Length [km] & RMD \\
\hline & Access & Number of accesses per kilometre & RMD \\
\hline & Parking & Number of available parking space & RMD \\
\hline \multirow[t]{12}{*}{ Intersections on national/secondary roads } & $A A D T$ & Annual average daily traffic [veh/day] & NTC \\
\hline & Location & Location in rural/urban areas & online maps \\
\hline & Control & Traffic control device (yield, stop, signals) & online maps \\
\hline & Bypass & Bypass lane (no/yes) & online maps \\
\hline & Turn & Turning lanes (no/yes) & online maps \\
\hline & Legs & Number of roundabout legs & online maps \\
\hline & $I C D$ & Roundabout inscribed circle diameter [m] & online maps \\
\hline & Island & Roundabout central island diameter [m] & online maps \\
\hline & Entry & Average of roundabout entry angles $\left[^{\circ}\right]$ & online maps \\
\hline & Deviation & Average of roundabout deviation angles $\left[{ }^{\circ}\right]$ & online maps \\
\hline & Circ & Width of roundabout circulatory lane [m] & online maps \\
\hline & Apron & Width of roundabout track apron [m] & online maps \\
\hline \multirow[t]{5}{*}{ Sections of national/secondary roads } & $A A D T$ & Annual average daily traffic [veh/day] & NTC \\
\hline & L & Length [km] & RMD \\
\hline & Urban & Ratio of location in urban areas & own GIS \\
\hline & Minor & Number of minor intersections per kilometre & online maps \\
\hline & $C C R$ & Curvature change rate [gon/km] & own GIS \\
\hline
\end{tabular}

${ }^{a}$ NTC national traffic census, RMD Road and Motorway Directorate of the Czech Republic

Additional Table 3 provides information on numbers of elements and descriptive characteristics of their accident data.

\subsection{Selection of model function form}

Accident prediction model equation consists of two parts: (1) exposure, i.e., AADT (and length, in case of sections), and (2) risk factors. In literature, various forms of considering road section risk exposure may be found, for example:

- both length and AADT in a power form [34, 39, 69]: $L^{\beta_{1}} \cdot(A A D T)^{\beta_{2}}$
- length as an offset and AADT in a power form $[20,80]: L \cdot(A A D T)^{\beta_{1}}$

- length in exponential form [17, 61]: $\exp \left(\beta_{1} \cdot L\right)$.

$(A A D T)^{\beta_{2}}$

In a previous Czech study [4], several model function forms were compared in terms of proportion of explained systematic variation, and models with power function of section length proved better. Therefore, it was also chosen for this study. For the models of intersections or conflict points, there is a relative consensus in literature [57, 68, 72, 89]: exposure is usually defined as a product of conflicting flows or a product of major 
Table 3 Numbers of elements and descriptive characteristics of their accident data

\begin{tabular}{llllll}
\hline Element type & Number & \multicolumn{4}{l}{ Accident frequency } \\
\cline { 3 - 6 } & & & & & \\
& & & & & \\
& & & & & \\
Min. & Max. & Mean & Sum \\
- Interchange conflict points & 2550 & 0 & 172 & 2.39 & 6095 \\
- Interchange ramps & 3636 & 0 & 178 & 3.03 & 11,029 \\
- Sections & 382 & 1 & 283 & 55.97 & 21,381 \\
National roads & & & & & \\
- 3-leg intersections & 536 & 0 & 46 & 5.51 & 2956 \\
- 4-leg intersections & 92 & 1 & 62 & 12.70 & 1168 \\
- Roundabouts & 67 & 0 & 110 & 11.69 & 783 \\
- Undivided sections & 311 & 0 & 130 & 25.89 & 8052 \\
- Divided sections & 53 & 0 & 152 & 10.49 & 556 \\
Secondary roads & & & & & \\
- 3-leg intersections & 165 & 0 & 33 & 1.65 & 273 \\
- 4-leg intersections & 39 & 0 & 31 & 5.77 & 225 \\
- Sections & 372 & 0 & 70 & 9.43 & 3507 \\
\hline
\end{tabular}

flow and proportion of minor flow. Model function forms adopted for this study, together with their linearized form, which will be used for modelling, were as follows:

1. for sections:

$$
\hat{N}=\exp \left(\beta_{0}\right) \cdot L^{\beta_{1}} \cdot(A A D T)^{\beta_{2}} \cdot \exp \left(\sum_{i=3}^{n}\left(\beta_{i} \cdot x_{i}\right)\right)
$$

in linearized form:

$$
\begin{aligned}
\ln (\hat{N})= & \beta_{0}+\beta_{1} \cdot \ln (L)+\beta_{2} \cdot \ln (A A D T) \\
& +\sum_{i=3}^{n}\left(\beta_{i} \cdot x_{i}\right)
\end{aligned}
$$

2. for intersections:

$$
\begin{array}{r}
N=\exp \left(\beta_{0}\right) \cdot\left(A A D T_{\text {major }}\right)^{\beta_{1}} \cdot\left(A A D T_{\text {minor }}\right)^{\beta_{2}} \cdot \exp \left(\sum_{i=3}^{n}\left(\beta_{i} \cdot x_{i}\right)\right) \\
(2 \mathrm{a}) \\
\hat{N}=\exp \left(\beta_{0}\right) \cdot\left(A A D T_{\text {major }}\right)^{\beta_{1}} \cdot\left(A A D T_{\text {proportion }}\right)^{\beta_{2}} \cdot \exp \left(\sum_{i=3}^{n}\left(\beta_{i} \cdot x_{i}\right)\right)
\end{array}
$$

$$
\hat{N}=\exp \left(\beta_{0}\right) \cdot\left(A A D T_{\text {sum }}\right)^{\beta_{1}} \cdot \exp \left(\sum_{i=2}^{n}\left(\beta_{i} \cdot x_{i}\right)\right)
$$

in linearized form:

$$
\begin{aligned}
\ln (\hat{N})= & \beta_{0}+\beta_{1} \cdot \ln \left(A A D T_{\text {major }}\right) \\
& +\beta_{2} \cdot \ln \left(A A D T_{\text {minor }}\right)+\sum_{i=3}^{n}\left(\beta_{i} \cdot x_{i}\right) \\
\ln (\hat{N})= & \beta_{0}+\beta_{1} \cdot \ln \left(A A D T_{\text {major }}\right) \\
& +\beta_{2} \cdot \ln \left(A A D T_{\text {proportion }}\right) \\
& +\sum_{i=3}^{n}\left(\beta_{i} \cdot x_{i}\right) \\
\ln (\hat{N})= & \beta_{0}+\beta_{1} \cdot \ln \left(A A D T_{\text {sum }}\right)+\sum_{i=2}^{n}\left(\beta_{i} \cdot x_{i}\right)
\end{aligned}
$$

where:

$\hat{N}$ predicted accident frequency for each severity level $L$ section length

$A A D T$ annual average daily traffic

$A A D T_{\text {major }}$ major road AADT

$A A D T_{\text {minor }}$ minor road AADT

$A A D T_{\text {sum }}$ sum of entering AADTs on roundabout legs

$A A D T_{\text {proportion }}$ proportion of minor road AADT to total $\operatorname{AADT}\left(\frac{A A D T_{\text {minor }}}{A A D T_{\text {major }}+A A D T_{\text {minor }}}\right)$

$x_{i}(i=1,2, \ldots)$ other explanatory variables (risk factors) $\beta_{0}$ regression constant, to be estimated in modelling $\beta_{i}(i=1,2, \ldots)$ regression coefficients, to be estimated in modelling

\section{Modelling, results and applications}

This section describes development of accident prediction models and accident modification factors and their application in road safety impact assessment and network safety ranking.

\subsection{Accident prediction models}

Using the described data, modelling was conducted with aim of developing accident prediction models for 11 categories (Table 1) and 8 severity levels (FAT, SEV, SLI, PDO, injury accidents, total accidents, plus combinations). The modelling, i.e. calibrating the mentioned function forms, entails estimating regression coefficients $\beta_{i}$ and obtain model equations. Explanatory variables $\left(x_{i}\right)$ were added stepwise, while controlling for achieved statistical significance and discarding non-significant variables. The process was performed using generalized linear modelling (GLM) procedure in IBM SPSS, with a negative binomial error structure and logarithmic link function.

However, it was found that modelling for categories of individual severity levels did not result in quality APMs, due to low frequencies of severe and fatal accidents. Therefore, consistently with Srinivasan and Bauer [75], alternative approach was taken: 
1. Developing APM for total accident frequency (\#total).

2. Determining average ratios of individual severity levels. For example, for fatalities (FAT):

$$
(\text { ratio })_{F A T}=\# F A T / \# \text { total }
$$

3. Regression constants of APMs for individual severity levels were obtained by multiplying the regression constant of total APM by individual ratios. For example:

$$
\left(\beta_{0}\right)_{F A T}=\left(\beta_{0}\right)_{\text {total }} \cdot(\text { ratio })_{F A T}
$$

This means, that APMs for individual severity levels of a specific category have different regression constants $\beta_{0}$, but uniform regression coefficients $\beta_{1}, \beta_{2}, \ldots$

During modelling, effect of several explanatory variables was found insignificant, for example:

- interchange conflict points: channelization by road marking, number of driving directions

- motorway sections: density of accesses, available parking space

- intersections on national roads: presence of bypass lane or turn lanes, location in rural/urban areas

- sections of national and secondary roads: location in urban areas, curvature change rate

More information, as well as comparison with other studies, is provided in a previous paper [10]. The list of final model forms is given in Table 4 . Specific values of regression parameters for each accident severity level are provided in the Appendix.

\subsection{Accident modification factors}

In addition to accident prediction models (APMs), also accident modification factors (AMFs) are required for conducting road safety impact assessments. However, as mentioned in the literature review, while AMFs are available internationally (especially in Nordic countries or Northern America), no comparable AMF studies for Czech condition exist. The exceptions were two before-after EB studies:

- Ambros et al. [5] estimated AMF for roundabout conversions. The obtained values were within a range indicated in an international review [29].

- Recently, Ambros et al. [7] also estimated effectiveness of traffic signal conversions. The results were partly consistent with international values [31].

The results of both studies were therefore relatively comparable to the international findings. While more studies are definitely needed to reach definite conclusion about transferability possibilities, for the current purpose it was assumed that using international AMF values will be acceptable. The approximate values of AMFs for typical countermeasures were collated, based on international sources $[26,31,46,48,58,84]$ and used as a recommended list to be used for conducting RSIA.

\subsection{Application in road safety impact assessment}

The APMs and AMFs, described in previous text, present the background for conducting RSIA on Czech primary roads. To be useful for practitioners, two tools were provided by CDV:

\begin{tabular}{|c|c|c|}
\hline Model & Element type & Model equation \\
\hline & Motorways & \\
\hline M01 & - Interchange conflict points & $\hat{N}=\beta_{0} \cdot\left(A A D T_{\text {major }}\right)^{\beta_{1}} \cdot\left(A A D T_{\text {minor }}\right)^{\beta_{2}} \cdot \exp ($ Type $) \cdot \exp ($ Signal $)$ \\
\hline M02 & - Interchange ramps & $\hat{N}=\beta_{0} \cdot A A D T^{\beta_{1}} \cdot L^{\beta_{2}} \cdot \exp ($ Curve $)$ \\
\hline \multirow[t]{2}{*}{ M03 } & - Sections & $\hat{N}=\beta_{0} \cdot A A D T^{\beta_{1}} \cdot L^{\beta_{2}}$ \\
\hline & National roads & \\
\hline M04 & - 3-leg intersections & $\hat{N}=\beta_{0} \cdot\left(A A D T_{\text {major }}\right)^{\beta_{1}} \cdot\left(A A D T_{\text {minor }}\right)^{\beta_{2}} \cdot \exp ($ Turn $)$ \\
\hline M05 & - 4-leg intersections & $\hat{N}=\beta_{0} \cdot\left(A A D T_{\text {major }}\right)^{\beta_{1}} \cdot\left(A A D T_{\text {proportion }}\right)^{\beta_{2}} \cdot \exp ($ Turn $)$ \\
\hline M06 & - Roundabouts & $\hat{N}=\beta_{0} \cdot\left(A A D T_{\text {sum }}\right)^{\beta_{1}} \cdot \exp ($ Legs $)$ \\
\hline M07 & - Undivided sections & $\hat{N}=\beta_{0} \cdot A A D T^{\beta_{1}} \cdot L^{\beta_{2}}$ \\
\hline \multirow[t]{2}{*}{ M08 } & - Divided sections & $\hat{N}=\beta_{0} \cdot \operatorname{AADT}^{\beta_{1}} \cdot L^{\beta_{2}} \cdot \exp \left(\beta_{3} \cdot\right.$ Minor $)$ \\
\hline & Secondary roads & \\
\hline $\mathrm{M} 09+10$ & - Intersections & $\hat{N}=\beta_{0} \cdot\left(A A D T_{\text {major }}\right)^{\beta_{1}} \cdot\left(A A D T_{\text {proportion }}\right)^{\beta_{2}}$ \\
\hline M11 & - Sections & $\hat{N}=\beta_{0} \cdot A A D T^{\beta_{1}} \cdot L^{\beta_{2}} \cdot \exp \left(\beta_{3} \cdot\right.$ Minor $)$ \\
\hline
\end{tabular}

Table 4 Overview of final accident prediction model forms 
- Practical guidelines, describing both theory and practice of RSIA, including worked example application of assessing road safety impacts of a planned city bypass [8].

- On-line application, ${ }^{1}$ which enables selection of bypass route in a map, entering data (AADT, road category, etc.) for both route elements, and calculation of predicted accident frequency (see Fig. 1).

The final predictions, summed over a selected route and transformed into accident costs, present the predicted costs of a contemplated project variant (for example, bypass). These may be compared to a do-nothing scenario (i.e., not building a bypass) in order to determine the expected safety change. Further comparison of these benefits to the project costs enables a simple cost-benefit analysis and economic evaluation.

\subsection{Application in network safety ranking}

The developed APMs were used to obtain predicted accident frequency $(\hat{N})$ for each section $(i)$. For the purpose of network safety ranking, Empirical Bayes estimate of expected accident frequency $(E B)$ was then calculated, using predicted accident frequency, reported accident frequency
$(N)$ and length-dependent overdispersion parameter [43]. Finally potential for safety improvement (PSI) was obtained as a difference between predicted accident frequency and EB estimate [63]:

$$
\begin{aligned}
& E B_{i}=w_{i} \cdot \hat{N}_{i}+\left(1-w_{i}\right) \cdot N_{i} \\
& w_{i}=k_{i} /\left(k_{i}+\hat{N}_{i}\right) \\
& k_{i}=k \cdot L_{i} \\
& P S I_{i}=E B_{i}-\hat{N}_{i}
\end{aligned}
$$

where:

$E B_{i}$ Empirical Bayes estimate $w_{i}$ weight

$\hat{N}_{i}$ predicted accident frequency

$N_{i}$ reported accident frequency

$k_{i}$ overdispersion parameter

$L_{i}$ section length

$P S I_{i}$ potential for safety improvement

Values of PSI were used for network screening and ranking. Given smaller sizes of 3-legs, 4-legs and roundabouts samples, they were combined into one group. Thus, descendent ranking enabled identifying hot spots in following five groups:

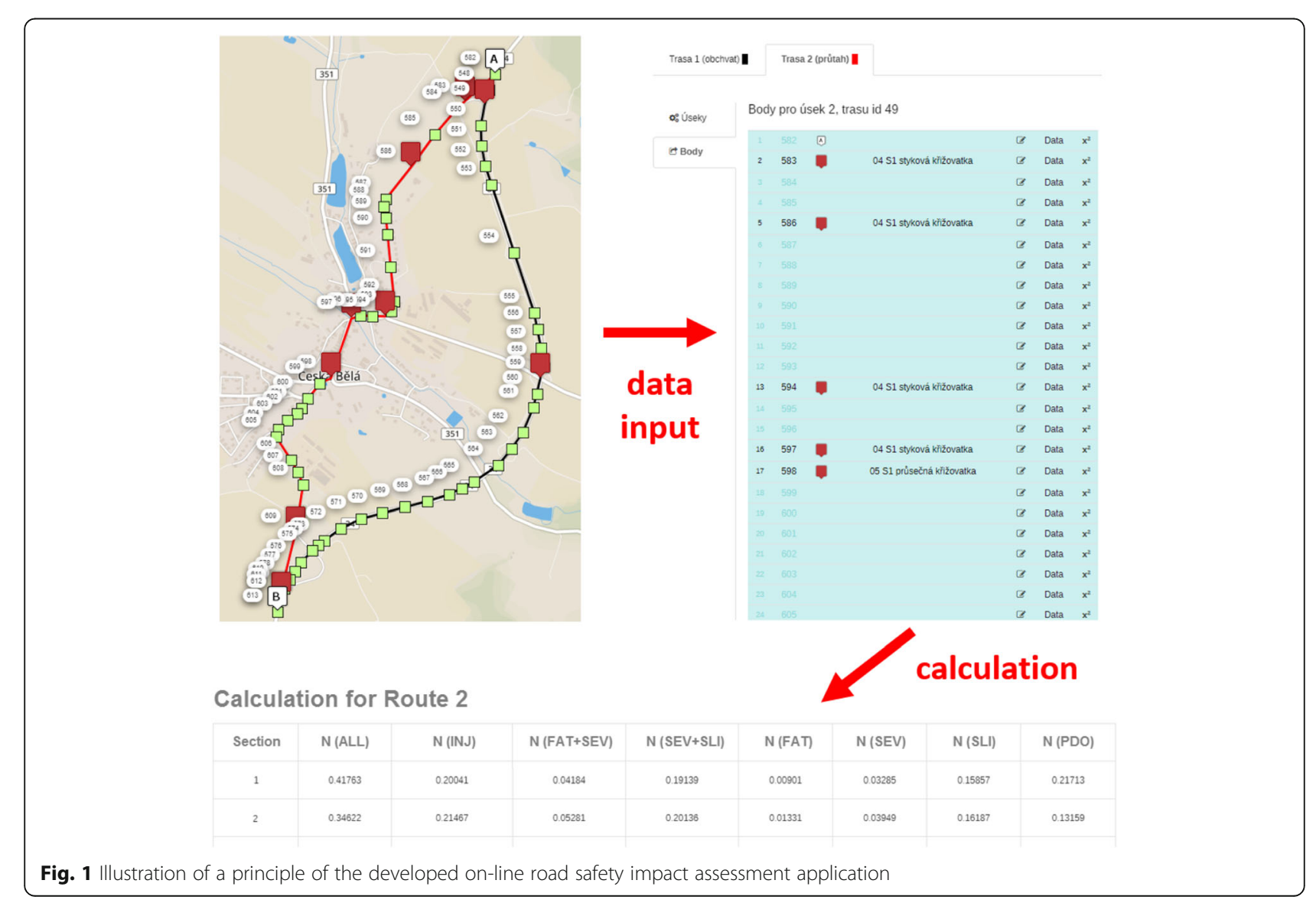




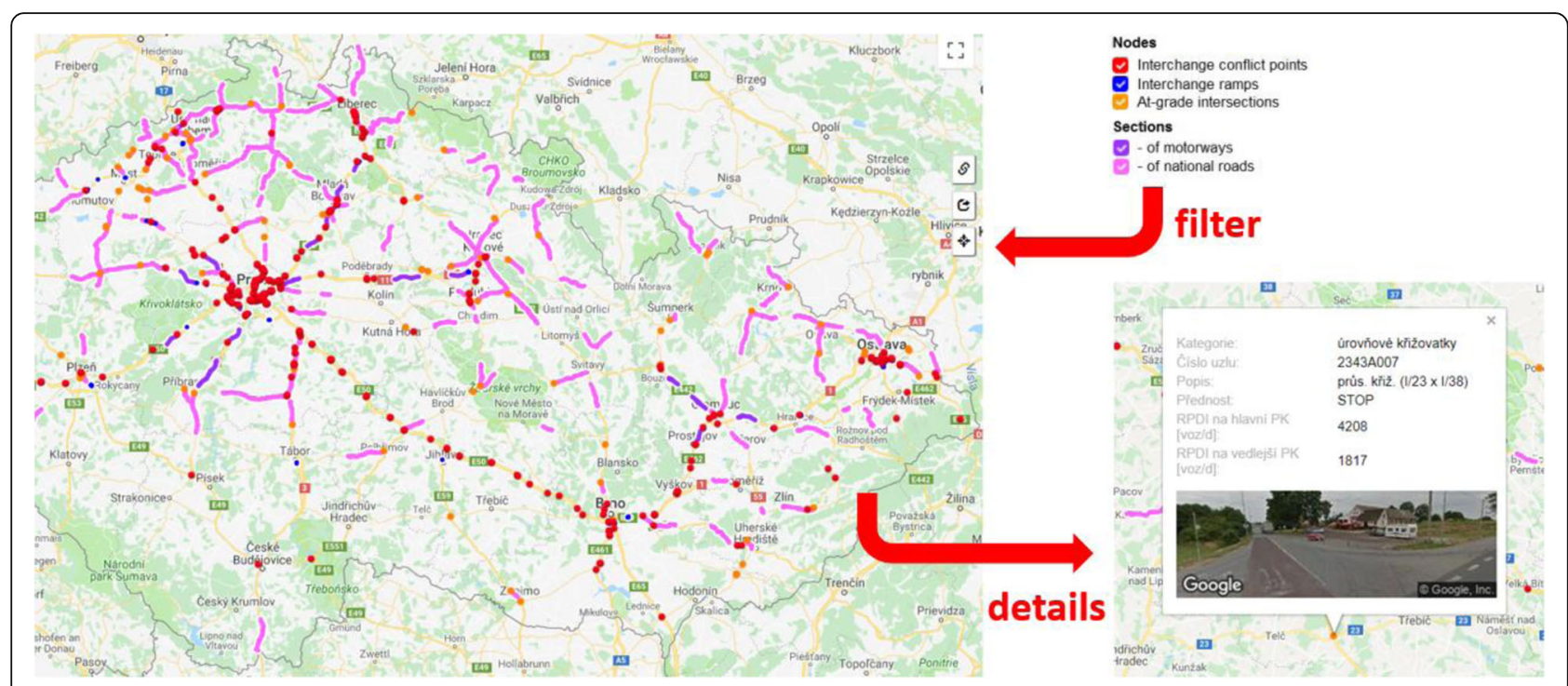

Fig. 2 Illustration of a principle of the developed on-line map with the results of network safety ranking

1. Interchange conflict points

2. Interchange ramps

3. Motorway sections

4. At-grade intersections on national roads

5. Sections of national roads

The ranked list of locations were visualized in an on-line map ${ }^{2}$ and handed over to the road agency, which will use them to prioritize and perform necessary steps to improve safety of Czech primary road network. Illustration is provided in Fig. 2: user may select specific elements using filter, and study their location including visualization of input data and a link to Google Street View map.

\section{Summary, discussion and conclusions}

Conduct of evidence-based road safety impact assessment and network safety ranking needs to be based on scientific tools: accident prediction models, accident modification factors and Empirical Bayes method. While such tools already exist in some countries, their transferability is limited. This motivated the authors to develop these tools in the Czech conditions, and describe this exercise in this paper. Unlike a number of similar international studies, which usually dealt only with a selected road category, the data and developed models had to consider not only road sections, but also intersections and interchanges. The focus was on Czech primary road network, consisting of motorways and national roads. In addition, the focus was widened to include also secondary roads, in order to enable assessment of impacts on adjacent road network.

The developed models enabled both identification of hazardous road locations (network safety ranking) and evaluation of safety of planned infrastructure (road safety impact assessment). The models also provided interpretation of influence of statistically significant risk factors. Effects of typical variables (AADT, length, number of intersection legs, etc.) were consistent with literature [68]. On the other hand, several variables did not have sufficiently significant effect (for example channelization, parking space along motorway or intersection bypass lanes). However, it is important to note, that the reported effects are only associations; in order to capture causal effects, one would need to conduct before-after studies. Another caveat is that although original dataset was relatively large, there is always a risk of omitted variable bias [54]. Examples of variables, which were not taken into account, may include for example speed behaviour. Another issue was use of proportions of observed accident severities in obtaining accident severity frequencies, caused by sample size limitations. While this has been used by some authors [58], it was noted as potentially biased, due to ignoring correlations between severities and traffic volumes [75].

Nevertheless, the current study helped establishing the framework for two practical procedures: road safety impact assessment and network safety ranking, including the examples of developed on-line tools. It may serve as an example for other member countries, which also lack their local tools. Follow-up studies may focus on future model updating and improvements (for example by adding some less available data such as grade, vertical alignment, pedestrian traffic or land use), as well as development of Czech accident modification factors to be used in selecting the most suitable countermeasures.

\section{Endnotes}

${ }^{1}$ Available at http://obchvaty.cdvinfo.cz/ (in Czech only).

${ }^{2}$ Available at http://sfdi.cdvgis.cz/ (in Czech only). 


\section{Appendix}

Table 5 Regression parameters of developed accident prediction models

\begin{tabular}{|c|c|c|c|c|c|c|c|c|c|c|}
\hline \multirow[t]{11}{*}{ M01 } & \multicolumn{10}{|c|}{$\hat{N}=\beta_{0} \cdot\left(A A D T_{\text {major }}\right)^{\beta_{1}} \cdot\left(A A D T_{\text {minor }}\right)^{\beta_{2}} \cdot \exp ($ Type $) \cdot \exp ($ Control $)$} \\
\hline & & & $\mathrm{ALL}$ & INJ & FAT+SEV & $\mathrm{SEV}+\mathrm{SLI}$ & FAT & SEV & SLI & PDO \\
\hline & \multicolumn{2}{|l|}{$\beta_{0}$} & $\begin{array}{l}7.185 \\
\text { E-05 }\end{array}$ & $\begin{array}{l}1.365 \\
E-05\end{array}$ & $\begin{array}{l}2.534 \\
\text { E-06 }\end{array}$ & $\begin{array}{l}1.286 \\
\text { E-05 }\end{array}$ & $\begin{array}{l}7.885 \\
E-07\end{array}$ & $\begin{array}{l}1.746 \\
\mathrm{E}-06\end{array}$ & $\begin{array}{l}1.112 \\
\text { E-05 }\end{array}$ & $\begin{array}{l}5.820 \\
E-05\end{array}$ \\
\hline & \multicolumn{2}{|l|}{$\beta_{1}$} & 0.671 & & & & & & & \\
\hline & \multicolumn{2}{|l|}{$\beta_{2}$} & 0.337 & & & & & & & \\
\hline & \multicolumn{2}{|c|}{ Type $=$ crossing } & 1.354 & & & & & & & \\
\hline & \multicolumn{2}{|c|}{$=$ roundabout } & 1.307 & & & & & & & \\
\hline & \multicolumn{2}{|c|}{$=$ merging } & 0.195 & & & & & & & \\
\hline & \multicolumn{2}{|c|}{$=$ diverging } & 0 & & & & & & & \\
\hline & \multicolumn{2}{|c|}{ Control $=$ no } & -0.761 & & & & & & & \\
\hline & \multicolumn{2}{|l|}{$=$ yes } & 0 & & & & & & & \\
\hline \multirow[t]{7}{*}{ M02 } & \multicolumn{10}{|c|}{$\hat{N}=\beta_{0} \cdot A A D T^{\beta_{1}} \cdot L^{\beta_{2}} \cdot \exp ($ Curve $)$} \\
\hline & & & ALL & INJ & FAT+SEV & $\mathrm{SEV}+\mathrm{SLI}$ & FAT & SEV & SLI & PDO \\
\hline & \multicolumn{2}{|l|}{$\beta_{0}$} & $\begin{array}{l}1.326 \\
E-03\end{array}$ & $\begin{array}{l}2.519 \\
\mathrm{E}-04\end{array}$ & $\begin{array}{l}4.676 \\
\text { E-05 }\end{array}$ & $\begin{array}{l}2.373 \\
\text { E-04 }\end{array}$ & $\begin{array}{l}1.455 \\
\text { E-05 }\end{array}$ & $\begin{array}{l}3.221 \\
E-05\end{array}$ & $\begin{array}{l}2.051 \\
\text { E-04 }\end{array}$ & $\begin{array}{l}1.074 \\
\text { E-03 }\end{array}$ \\
\hline & \multicolumn{2}{|l|}{$\beta_{1}$} & 0.772 & & & & & & & \\
\hline & \multicolumn{2}{|l|}{$\beta_{2}$} & 0.612 & & & & & & & \\
\hline & \multicolumn{2}{|c|}{ Curve $=$ curved } & 0.624 & & & & & & & \\
\hline & \multicolumn{2}{|c|}{$=$ straight } & 0 & & & & & & & \\
\hline \multirow[t]{5}{*}{ M03 } & \multicolumn{10}{|c|}{$\hat{N}=\beta_{0} \cdot A A D T^{\beta_{1}} \cdot L^{\beta_{2}}$} \\
\hline & & & ALL & INJ & FAT+SEV & $\mathrm{SEV}+\mathrm{SLI}$ & FAT & SEV & SLI & PDO \\
\hline & \multicolumn{2}{|l|}{$\beta_{0}$} & $\begin{array}{l}2.702 \\
E-04\end{array}$ & $\begin{array}{l}5.133 \\
\text { E-05 }\end{array}$ & $\begin{array}{l}9.529 \\
E-06\end{array}$ & $\begin{array}{l}4.837 \\
\text { E-05 }\end{array}$ & $\begin{array}{l}2.965 \\
\mathrm{E}-06\end{array}$ & $\begin{array}{l}6.564 \\
E-06\end{array}$ & $\begin{array}{l}4.180 \\
\text { E- } 05\end{array}$ & $\begin{array}{l}2.188 \\
\text { E-04 }\end{array}$ \\
\hline & \multicolumn{2}{|l|}{$\beta_{1}$} & 0.967 & & & & & & & \\
\hline & \multicolumn{2}{|l|}{$\beta_{2}$} & 0.699 & & & & & & & \\
\hline \multirow[t]{7}{*}{ M04 } & \multicolumn{10}{|c|}{$\hat{N}=\beta_{0} \cdot\left(A A D T_{\text {major }}\right)^{\beta_{1}} \cdot\left(A A D T_{\text {minor }}\right)^{\beta_{2}} \cdot \exp ($ Turn $)$} \\
\hline & & & ALL & INJ & FAT+SEV & $\mathrm{SEV}+\mathrm{SLI}$ & FAT & SEV & SLI & PDO \\
\hline & Rural & $\beta_{0}$ & $\begin{array}{l}4.982 \\
E-04\end{array}$ & $\begin{array}{l}2.392 \\
E-04\end{array}$ & $\begin{array}{l}4.994 \\
\text { E-05 }\end{array}$ & $\begin{array}{l}2.284 \\
E-04\end{array}$ & $\begin{array}{l}1.075 \\
\text { E-05 }\end{array}$ & $\begin{array}{l}3.919 \\
E-05\end{array}$ & $\begin{array}{l}1.892 \\
\text { E-04 }\end{array}$ & $\begin{array}{l}2.591 \\
E-04\end{array}$ \\
\hline & & $\beta_{1}$ & 0.481 & & & & & & & \\
\hline & & $\beta_{2}$ & 0.476 & & & & & & & \\
\hline & & Turn = yes & -0.267 & & & & & & & \\
\hline & & $=$ no & 0 & & & & & & & \\
\hline M05 & $\hat{N}=\beta$ & $\left.D T_{\text {major }}\right)^{\beta_{1}} \cdot(A A$ & portion $)^{\beta_{2}}$ & $($ Turn $)$ & & & & & & \\
\hline & & & ALL & INJ & FAT+SEV & SEV+SLI & FAT & SEV & SLI & PDO \\
\hline & Rural & $\beta_{0}$ & $\begin{array}{l}2.777 \\
E-03\end{array}$ & $\begin{array}{l}1.722 \\
\text { E-03 }\end{array}$ & $\begin{array}{l}4.235 \\
E-04\end{array}$ & $\begin{array}{l}1.615 \\
\text { E-03 }\end{array}$ & $\begin{array}{l}1.067 \\
\text { E-04 }\end{array}$ & $\begin{array}{l}3.168 \\
E-04\end{array}$ & $\begin{array}{l}1.298 \\
\text { E-03 }\end{array}$ & $\begin{array}{l}1.055 \\
\text { E-03 }\end{array}$ \\
\hline & & $\beta_{1}$ & 0.907 & & & & & & & \\
\hline & & $\beta_{2}$ & 0.772 & & & & & & & \\
\hline & & Turn = yes & -0.558 & & & & & & & \\
\hline & & $=$ no & 0 & & & & & & & \\
\hline
\end{tabular}


Table 5 Regression parameters of developed accident prediction models (Continued)

\begin{tabular}{|c|c|c|c|c|c|c|c|c|c|c|}
\hline \multirow[t]{6}{*}{$\overline{M 06}$} & \multicolumn{10}{|c|}{$\hat{N}=\beta_{0} \cdot\left(A A D T_{\text {sum }}\right)^{\beta_{1}} \cdot \exp ($ Legs $)$} \\
\hline & & & ALL & INJ & FAT+SEV & SEV+SLI & FAT & SEV & SLI & PDO \\
\hline & \multicolumn{2}{|l|}{$\beta_{0}$} & $\begin{array}{l}1.273 \\
\text { E-05 }\end{array}$ & $\begin{array}{l}4.329 \\
\text { E-06 }\end{array}$ & $\begin{array}{l}3.516 \\
\text { E-07 }\end{array}$ & $\begin{array}{l}4.304 \\
E-06\end{array}$ & $\begin{array}{l}2.598 \\
E-08\end{array}$ & $\begin{array}{l}3.256 \\
\mathrm{E}-07\end{array}$ & $\begin{array}{l}3.978 \\
\text { E- } 06\end{array}$ & $\begin{array}{l}8.404 \\
\text { E-06 }\end{array}$ \\
\hline & \multicolumn{2}{|l|}{$\beta_{1}$} & 1.220 & & & & & & & \\
\hline & \multicolumn{2}{|c|}{ Legs $=3$} & -0.464 & & & & & & & \\
\hline & \multicolumn{2}{|l|}{$=4$} & 0 & & & & & & & \\
\hline \multirow[t]{8}{*}{ M07 } & \multicolumn{10}{|c|}{$\hat{N}=\beta_{0} \cdot A A D T^{\beta_{1}} \cdot L^{\beta_{2}}$} \\
\hline & & & $\mathrm{ALL}$ & INJ & FAT+SEV & SEV+SLI & FAT & SEV & SLI & PDO \\
\hline & \multirow[t]{3}{*}{ Rural } & $\beta_{0}$ & $\begin{array}{l}4.780 \\
E-02\end{array}$ & $\begin{array}{l}1.721 \\
E-02\end{array}$ & $\begin{array}{l}3.421 \\
\text { E-03 }\end{array}$ & $\begin{array}{l}1.598 \\
E-02\end{array}$ & $\begin{array}{l}1.227 \\
E-03\end{array}$ & $\begin{array}{l}2.194 \\
E-03\end{array}$ & $\begin{array}{l}1.379 \\
E-02\end{array}$ & $\begin{array}{l}3.059 \\
\mathrm{E}-02\end{array}$ \\
\hline & & $\beta_{1}$ & 0.434 & & & & & & & \\
\hline & & $\beta_{2}$ & 0.584 & & & & & & & \\
\hline & \multirow[t]{3}{*}{ Urban } & $\beta_{0}$ & $\begin{array}{l}9.142 \\
\text { E-03 }\end{array}$ & $\begin{array}{l}3.382 \\
\text { E-03 }\end{array}$ & $\begin{array}{l}4.687 \\
\text { E-04 }\end{array}$ & $\begin{array}{l}3.274 \\
E-03\end{array}$ & $\begin{array}{l}1.081 \\
\text { E-04 }\end{array}$ & $\begin{array}{l}3.606 \\
E-04\end{array}$ & $\begin{array}{l}2.914 \\
\text { E-03 }\end{array}$ & $\begin{array}{l}5.759 \\
\text { E-03 }\end{array}$ \\
\hline & & $\beta_{1}$ & 0.648 & & & & & & & \\
\hline & & $\beta_{2}$ & 0.713 & & & & & & & \\
\hline \multirow[t]{6}{*}{ M08 } & \multicolumn{10}{|c|}{$\hat{N}=\beta_{0} \cdot A A D T^{\beta_{1}} \cdot L^{\beta_{2}} \cdot \exp \left(\beta_{3} \cdot\right.$ Minor $)$} \\
\hline & & & ALL & INJ & FAT+SEV & SEV+SLI & FAT & SEV & SLI & PDO \\
\hline & $\beta_{0}$ & & $\begin{array}{l}6.607 \\
E-04\end{array}$ & $\begin{array}{l}2.378 \\
\text { E-04 }\end{array}$ & $\begin{array}{l}4.728 \\
\text { E-05 }\end{array}$ & $\begin{array}{l}2.209 \\
\text { E-04 }\end{array}$ & $\begin{array}{l}1.696 \\
E-05\end{array}$ & $\begin{array}{l}3.032 \\
E-05\end{array}$ & $\begin{array}{l}1.906 \\
\text { E-04 }\end{array}$ & $\begin{array}{l}4.228 \\
\text { E-04 }\end{array}$ \\
\hline & $\beta_{1}$ & & 0.842 & & & & & & & \\
\hline & $\beta_{2}$ & & 1.094 & & & & & & & \\
\hline & $\beta_{3}$ & & 0.216 & & & & & & & \\
\hline \multirow[t]{8}{*}{ M09+10 } & \multicolumn{10}{|c|}{$\hat{N}=\beta_{0} \cdot\left(A A D T_{\text {major }}\right)^{\beta_{1}} \cdot\left(A A D T_{\text {proportion }}\right)^{\beta_{2}}$} \\
\hline & & & ALL & INJ & FAT+SEV & SEV+SLI & FAT & SEV & SLI & PDO \\
\hline & \multirow[t]{3}{*}{ 3-leg } & $\beta_{0}$ & $\begin{array}{l}3.842 \\
\text { E-05 }\end{array}$ & $\begin{array}{l}2.612 \\
E-05\end{array}$ & $\begin{array}{l}4.706 \\
\text { E-06 }\end{array}$ & $\begin{array}{l}2.463 \\
E-05\end{array}$ & $\begin{array}{l}1.492 \\
\text { E-06 }\end{array}$ & $\begin{array}{l}3.214 \\
\text { E-06 }\end{array}$ & $\begin{array}{l}2.142 \\
E-05\end{array}$ & $\begin{array}{l}1.229 \\
\text { E-05 }\end{array}$ \\
\hline & & $\beta_{1}$ & 1.221 & & & & & & & \\
\hline & & $\beta_{2}$ & 0.507 & & & & & & & \\
\hline & \multirow[t]{3}{*}{ 4-leg } & $\beta_{0}$ & $\begin{array}{l}9.272 \\
E-05\end{array}$ & $\begin{array}{l}6.305 \\
E-05\end{array}$ & $\begin{array}{l}1.136 \\
E-05\end{array}$ & $\begin{array}{l}5.945 \\
E-05\end{array}$ & $\begin{array}{l}3.600 \\
E-06\end{array}$ & $\begin{array}{l}7.757 \\
E-06\end{array}$ & $\begin{array}{l}5.169 \\
E-05\end{array}$ & $\begin{array}{l}2.967 \\
\text { E-05 }\end{array}$ \\
\hline & & $\beta_{1}$ & 1.278 & & & & & & & \\
\hline & & $\beta_{2}$ & 1.004 & & & & & & & \\
\hline \multirow[t]{7}{*}{ M11 } & \multicolumn{10}{|c|}{$\hat{N}=\beta_{0} \cdot A A D T^{\beta_{1}} \cdot L^{\beta_{2}} \cdot \exp \left(\beta_{3} \cdot\right.$ Minor $)$} \\
\hline & & ALL & INJ & FAT+SEV & SEV+SLI & & FAT & SEV & SLI & PDO \\
\hline & \multirow[t]{2}{*}{$\beta_{0}$} & 6.543 & $\begin{array}{l}4.450 \\
F-04\end{array}$ & $\begin{array}{l}8.015 \\
F-05\end{array}$ & $\begin{array}{l}4.195 \\
F-04\end{array}$ & & $\begin{array}{l}2.541 \\
F-05\end{array}$ & $\begin{array}{l}5.475 \\
F-05\end{array}$ & $\begin{array}{l}3.648 \\
F-04\end{array}$ & $\begin{array}{l}2.094 \\
F-04\end{array}$ \\
\hline & & E-04 & & & & & & & & \\
\hline & $\beta_{1}$ & 0.885 & & & & & & & & \\
\hline & $\beta_{2}$ & 0.985 & & & & & & & & \\
\hline & $\beta_{3}$ & 0.091 & & & & & & & & \\
\hline
\end{tabular}

For interpretation of model types (M01, .., M11) see Tables 1 and 4

As introduced in Section 3.3, severity levels are FAT, SEV, SLI, PDO, plus combinations: FAT+SEV, SEV+SLI, INJ (injury accidents), ALL (all accidents)

Explanatory variables (abbreviations, definitions, units) are listed in Table 2 and Section 3.4

Regression constants $\left(\beta_{0}\right)$ are reported using scientific notation (e.g., 7.185E-05 $=7.185 \cdot 10^{-5}$ ) 


\section{Acknowledgements}

The authors appreciate the help of their colleagues with the related projects (Martina Bílová, Vojtěch Cícha, Vladimír Dufek, Jan Elgner, Ondřej Gogolín, Pavel Havránek, Ivo Hlavůněk, Zuzana Křivánková, Martin Kyselý, Dominika Mikšová, Jan Novák, Kristýna Procházková, Stanislav Řehák, Jiři Sedoník, Ondřej Valach, Veronika Valentová, Lucie Vyskočilová, Ivo Zahradníček). The authors also thank Mariusz Kieć (Cracow University of Technology) and Chris Jurewicz (ARRB Group Ltd) for valuable advices and discussions. The paper was produced with the financial support of Czech Ministry of Education, Youth and Sports under the National Sustainability Programme I project of Transport R\&D Centre (LO1610), using the research infrastructure from the Operation Programme Research and Development for Innovations (CZ.1.05/ 2.1.00/03.0064).

\section{Authors' contributions}

All authors read and approved the final manuscript.

\section{Competing interests}

The authors declare that they have no competing interests.

\section{Publisher's Note}

Springer Nature remains neutral with regard to jurisdictional claims in published maps and institutional affiliations.

\section{Received: 3 April 2018 Accepted: 8 November 2018}

Published online: 03 January 2019

\section{References}

1. AASHTO (2010) Highway Safety Manual, first edn. American Association of State Highway and Transportation Officials (AASHTO), Washington, DC

2. Abbas KA (2004) Traffic safety assessment and development of predictive models for accidents on rural roads in Egypt. Accid Anal Prev 36(2):149-163

3. Ambros J, Novák J, Borsos A, Hóz E, Kieć M, Machciník Š, Ondrejka R (2016) Central European comparative study of traffic safety on roundabouts. Transp Res Procedia 14:4200-4208

4. Ambros J, Sedoník J (2016) A feasibility study for developing a transferable accident prediction model for Czech regions. Transp Res Procedia 14:2054-2063

5. Ambros J, Turek R, Janoška Z (2016) Safety evaluation of Czech roundabouts. Adv Transp Stud 40:111-122

6. Ambros J, Valentová V, Sedoník J (2016) Developing updatable crash prediction model for network screening: case study of Czech two-lane rural road segments. Transp Res Rec 2583:1-7

7. Ambros J, Turek R, Brich M (2017) Are traffic safety decisions based on evidence? Paper presented at the 30th ICTCT workshop, Olomouc

8. Ambros J, Turek R, Havránek P, Novák J, Valentová V (2017) Metodika hodnocení dopadu silniční infrastruktury na bezpečnost. CDV - Transport Research Centre, Brno

9. Ambros J, Jurewicz C, Turner S, Kieć M (2018) An international review of challenges and opportunities in development and use of crash prediction models. Eur Transp Res Rev 10:35

10. Ambros J, Turek R, Brich M, Mikšová D (2018) Safety screening of Czech core road network. Paper presented at the 97th Transportation Research Board Annual Meeting, Washington, DC

11. Ambros J, Sedoník J, Krivaánková Z (2018) How to simplify road network safety screening? Adv Transp Stud 44:151-158

12. Andres J, Mikulík J, Rokytová J, Hrubý Z, Skládaný P (2001) Metodika identifikace a rešení míst častých dopravních nehod. CDV - Transport Research Centre, Brno

13. Avelar RE, Dixon KK, Escobar P (2015) Evaluation of signalized-intersection crash screening methods based on distance from intersection. Transp Res Rec 2514:177-186

14. ASTRA (2013) Ermittlung von Kennzahlen für NSM (Netzeinstufung) und RIA (Folgeabschätzung). Report N294-0243. Federal Roads Office (ASTRA), Berne

15. Barbosa H, Cunto F, Bezerra B, Nodari C, Jacques MA (2014) Safety performance models for urban intersections in Brazil. Accid Anal Prev 70:258-266

16. Bartoš L, Martolos J (2012) Stanovení intenzit dopravy na pozemních komunikacích, II. vydání. Technical guidelines 189. EDIP, Plzeň
17. Bauer KM, Harwood DW (1998) Statistical models of accidents on interchange ramps and speed-change lanes. Report FHWA-RD-97-106. Federal Highway Administration, Washington, DC

18. Biancardo SA, Russo F, Žlionienė D, Zhang W (2017) Rural two-lane twoway three-leg and four-leg stop-controlled intersections: predicting road safety effects. Baltic J Road Bridge Eng 12(2):117-126

19. BMVIT (2006) Leitfaden zur Erstellung des Umweltberichtes im Rahmen der strategischen Prüfung - Verkehr für Netzveränderungen im hochrangigen Bundesverkehrswegenetz (SP-V-Leitfaden, Version 2.1). Ministry for Transport, Innovation and Technology (BMVIT), Vienna

20. Bonneson JA, Geedipally S, Pratt MP, Lord D (2012) NCHRP project 17-45 final report: safety prediction methodology and analysis tool for freeways and interchanges. Transportation Research Board, Washington, DC

21. Bornheimer C, Schrock S, Wang M, Lubliner H (2012) Developing a regional safety performance function for rural two-lane highways. Paper presented at the 91st Transportation Research Board Annual Meeting, Washington, DC

22. Borsos A, Cafiso S, D'Agostino C, Miletics D (2016) Comparison of Italian and Hungarian black spot ranking. Transp Res Procedia 14:2148-2157

23. Cafiso S, Di Graziano A, Di Silvestro G, La Cava G, Persaud B (2010) Development of comprehensive accident models for two-lane rural highways using exposure, geometry, consistency and context variables. Accid Anal Prev 42(4):1072-1079

24. Caliendo CM, Guida M, Parisi A (2007) A crash-prediction model for multilane roads. Accid Anal Prev 39(4):657-670

25. Canale S, Distefano N, Leonardi S (2013) Interchanges safety: forecast model based on ISAT algorithm. Int J Traffic Transp Eng 3(3):243-259

26. CEDR (2008) Best practice for cost-effective road safety infrastructure investments. Conference of European Directors of Roads (CEDR), Paris

27. Deublein M, Schubert M, Adey BT, Köhler J, Faber MH (2013) Prediction of road accidents: a bayesian hierarchical approach. Accid Anal Prev 51:274-291

28. Dupont E, Muhlrad N, Buttler I, Gitelman V, Giustiniani G, Jähi H, Machata K, Martensen H, Papadimitriou E, Persia L, Talbot R, Vallet G, Wijnen W, Yannis G (2012) Needs for evidence-based road safety decision making in Europe. Procedia Soc Behav Sci 48:2513-2522

29. Elvik R (2003) Effects on road safety of converting intersections to roundabouts: review of evidence from non-US studies. Transp Res Rec 1847:1-10

30. Elvik R (2008) A survey of operational definitions of hazardous road locations in some European countries. Accid Anal Prev 40(6):1830-1835

31. Elvik R, Høye A, Vaa T, Sørensen M (2009) The handbook of road safety measures, Second edn. Emerald, Bingley

32. ETSC (1997) Road safety audit and safety impact assessment. European Transport Safety Council (ETSC), Brussels

33. FGSV (1997) Empfehlungen für Wirtschaftlichkeitsuntersuchungen an Straßen (EWS). Forschungsgesellschaft für Straßen- und Verkehrswesen (FGSV), Cologne

34. Garach L, de Oña J, López G, Baena L (2016) Development of safety performance functions for Spanish two-lane rural highways on flat terrain. Accid Anal Prev 95:250-265

35. Garnowski M, Manner H (2011) On factors related to car accidents on German autobahn connectors. Accid Anal Prev 43(5):1864-1871

36. Gemy F, Besnard F, Marsolat R, Le Moing S, Thieulin A, Tremblin G (2012) Guide méthodologique: évaluation des incidences sur la sécurité routière. Ministry of Ecology, Sustainable Development and Energy, Paris

37. Geurts K, Wets G (2003) Black spot analysis methods: literature review. Report RA-2003-07. Policy Research Centre for Mobility and Public Works, Diepenbeek

38. Gross F, Persaud B, Lyon C (2010) A guide to developing quality crash modification factors. Report FHWA-SA-10-032. Federal Highway Administration, Washington, DC

39. Hadi MA, Aruldhas J, Chow L-F, Wattleworth JA (1995) Estimating safety effects of cross-section design for various highway types using negative binomial regression. Transp Res Rec 1500:169-177

40. Hasson P, Kauppila J, Assing K, Yannis G, Lassarre S (2012) Challenges and opportunities for the assessment of the effectiveness of road safety measures. Procedia Soc Behav Sci 48:3230-3238

41. Hauer E (1995) On exposure and accident rate. Traffic Eng Control 36(3): 134-138

42. Hauer E (1997) Observational before-after studies in road safety: estimating the effect of highway and traffic engineering measures on road safety. Pergamon, Oxford

43. Hauer E (2001) Overdispersion in modelling accidents on road sections and in empirical Bayes estimation. Accid Anal Prev 33(6):799-808 
44. Hauer E, Harwood DW, Council FM, Griffith MS (2002) Estimating safety by the empirical Bayes method: a tutorial. Transp Res Rec 1784:126-131

45. Hauer E (2007) A case for evidence-based road-safety delivery. In: Improving traffic safety culture in the United States: the journey forward. AAA Foundation for Traffic Safety, Washington, DC, pp 329-343

46. Høye A, Elvik R, Sørensen MWJ (2011) Effects of road safety measures: a summary for use in impact assessment. Report 1157/2011. Institute of Transport Economics, Oslo

47. Høye A (2016) Development of crash prediction models for national and county roads in Norway (2010-2015). Report 1522/2016. Institute of Transport Economics, Oslo

48. Høye A (2017) Compendium of road safety measures. Report 1556/2017. Institute of Transport Economics, Oslo

49. La Torre F, Tanzi N, Yannis G, Dragomanovits A, Richter T, Ruhl S, Karathodorou N, Graham D (2018) Accident prediction in European countries - development of a practical evaluation tool. Paper presented at the 7th Transport Research Arena, Vienna

50. Laurinavičius A, Grigonis V, Ušpalytè-Vitkūnienẻ R, Ratkevičiūte K, Čygaitè L, Skrodenis E, Antov D, Smirnovs J, Bobrovaitè-Jurkonè B (2012) Policy instruments for managing EU road safety targets: road safety impact assessment. Baltic J Road Bridge Eng 7(1):60-67

51. McCartt AT, Shabanova Northrup V, Retting RA (2004) Types and characteristics of ramp-related motor vehicle crashes on urban interstate roadways in northern Virginia. J Saf Res 35(1):107-114

52. Meuleners L, Fraser M (2008) Review of the WA state black spot program: a literature review of Australian and international black spot programs. Curtin University of Technology, Perth

53. MIP (2012) Smernica za izdelavo ocene učinka na varnost v prometu (RSIA). Ministry of Infrastructure (MIP), Ljubljana

54. Mitra S, Washington S (2012) On the significance of omitted variables in intersection crash modeling. Accid Anal Prev 49:439-448

55. Montella A, Colantuoni L, Lamberti R (2008) Crash prediction models for rural motorways. Transp Res Rec 2083:180-189

56. Montella A (2010) A comparative analysis of hotspot identification methods. Accid Anal Prev 42(2):571-581

57. Nambuusi B, Brijs T, Hermans E (2008) A review of accident prediction models for road intersections. Report RA-MOW-2008-004. Policy Research Centre for Mobility and Public Works, Diepenbeek

58. NZ Transport Agency (2016) Crash estimation compendium (New Zealand crash risk factors guideline). NZ Transport Agency (NZTA), Wellington

59. OECD (2012) Sharing road safety: developing an international framework for crash modification functions. Organisation for Economic Co-operation and Development (OECD), Paris

60. Oh J, Washington S, Choi K (2004) Development of accident prediction models for rural highway intersections. Transp Res Rec 1897:18-27

61. Parajuli B, Persaud B, Lyon C, Munro J (2006) Safety performance assessment of freeway interchanges, ramps, and ramp terminals. Paper presented at 2006 Annual Conference of the Transportation Association of Canada, Charlottetown

62. Peltola H, Rajamäki R, Luoma J (2013) A tool for safety evaluations of road improvements. Accid Anal Prev 60:277-288

63. Persaud B, Lyon C, Nguyen T (1999) Empirical Bayes procedure for ranking sites for safety investigation by potential for safety improvement. Transp Res Rec 1665:7-12

64. Persaud B, Lyon C (2007) Empirical Bayes before-after safety studies: lessons learned from two decades of experience and future directions. Accid Anal Prev 39(3):546-555

65. Persaud B, Saleem T, Faisal S, Lyon C, Chen Y, Sabbaghi A (2012) Adoption of Highway Safety Manual predictive methodologies for Canadian highways. In: 2006 Annual Conference of the Transportation Association of Canada, Fredericton

66. PIARC (2015) Road safety manual: a manual for practitioners and decision makers on implementing safe system infrastructure. World Road Association (PIARC), Paris

67. Qin X, Wellner A (2012) Segment length impact on highway safety screening analysis. Paper presented at the 91st Transportation Research Board Annual Meeting, Washington, DC

68. Reurings M, Janssen T, Eenink R, Elvik R, Cardoso J, Stefan C (2005) Accident prediction models and road safety impact assessment: a state-of-the-art. RIPCORD-ISEREST project deliverable 2.1. European Commission, Brussels
69. Reurings M, Janssen T (2007) Accident prediction models for urban and rural carriageways. Report R-2006-14. SWOV Institute for Road Safety Research, Leidschendam

70. RMD (2017) Roads and motorways in the Czech Republic 2016. Road and Motorway Directorate of the Czech Republic (RMD), Prague

71. Sacchi E, Persaud B, Bassani M (2012) Assessing international transferability of highway safety manual crash prediction algorithm and its components. Transp Res Rec 2279:90-98

72. Satterthwaite SP (1981) A survey of research into relationships between traffic accidents and traffic volumes. Supplementary report 692. Transport and Road Research Laboratory, Crowthorne

73. Shankar V, Mannering F, Barfield W (1996) Statistical analysis of accident severity on rural freeways. Accid Anal Prev 28(3):391-401

74. Shen J, Gan A (2003) Development of crash reduction factors: methods, problems, and research needs. Transp Res Rec 1840:50-56

75. Srinivasan R, Bauer K (2013) Safety performance function development guide: developing jurisdiction-specific SPFs. Report FHWA-SA-14-005. Federal Highway Administration, Washington, DC

76. Sun X, Li Y, Magri D, Shirazi HH (2006) Application of highway safety manual draft chapter: Louisiana experience. Transp Res Rec 1950:55-64

77. Šenk P, Ambros J (2011) Estimation of accident frequency at newly-built roundabouts in the Czech Republic. Trans Transp Sci 4(4):199-206

78. Thomas R, Gallon CA (1998) Motorway accidents: associations between characteristics - related variables. Traffic Eng Control 29(9):456-465

79. TML (2014) Study on the effectiveness and on the improvement of the EU legislative framework on road infrastructure safety management: ex post evaluation - final report. Transport \& Mobility Leuven (TML), Leuven

80. Torbic DJ, Harwood DW, Gilmore DK, Richard KR (2007) Interchange Safety Analysis Tool (ISAT): user manual. Report FHWA-HRT-07-045. Federal Highway Administration, Washington, DC

81. Torbic DJ, Harwood DW, Bauer KM (2017) Application of highway safety manual method for ramp crash prediction to loop and diamond ramps. Transp Res Rec 2636:43-52

82. Trafikverket (2017) Bygg om eller bygg nytt. Kapitel 6 Trafiksäkerhet. Swedish Transport Administration (Trafikverket), Borlänge

83. Twomey JM, Heckman ML, Hayward JC, Zuk RJ (1993) Accidents and safety associated with interchanges. Transp Res Rec 1385:100-105

84. Turner B, Steinmetz L, Lim A, Walsh K (2012) Effectiveness of road safety engineering treatments. Publication AP-R422-12. Austroads, Sydney

85. Universitas-Győr (2015) A közúti biztonsági hatásvizsgálati útmutató felülvizsgálata. Universitas-Győr Nonprofit Kft., Győr

86. Valentová V, Ambros J, Janoška Z (2014) A comparative analysis of identification of hazardous locations in regional rural road network. Adv Transp Stud 34:57-66

87. van der Sluis J, Janssen T (2000) A method to assess road safety of planned infrastructure. Report D-2000-14. SWOV Institute for Road Safety Research, Leidschendam

88. Vejdirektoratet (2015) Håndbog trafiksikkerhedsberegninger og ulykkesbekæmpelse. Danish Road Directorate (Vejdirektoratet), Copenhagen

89. Vieira Gomes S, Geedipally SR, Lord D (2012) Estimating the safety performance of urban intersections in Lisbon, Portugal. Saf Sci 50(9): $1732-1739$

90. Vyskočilová A, Gogolín O, Valach O (2014) New approach to evaluation of socio-economic losses caused by traffic accidents. Paper presented at the 93rd Transportation Research Board Annual Meeting, Washington, DC

91. Wegman FCM, Roszbach R, Mulder JAG, Schoon CC, Poppe F (1994) Road safety impact assessment (RIA): a proposal for tools and procedures for a RIA. Report R-94-20. SWOV Institute for Road Safety Research, Leidschendam

92. Wegman F, Berg H-Y, Cameron I, Thompson C, Siegrist S, Weijermars W (2015) Evidence-based and data-driven road safety management. IATSS Res 39(1):19-25

93. Wong SC, Sze NN, Li YC (2007) Contributory factors to traffic crashes at signalized intersections in Hong Kong. Accid Anal Prev 39(6):1107-1113

94. Xie F, Gladhill K, Dixon KK, Monsere CM (2011) Calibrating the highway safety manual predictive models for Oregon state highways. Transp Res Rec 2241:19-28

95. Yannis G, Weijermars W, Kauppila J (2012) A review of international sources for road safety measures assessment. Procedia Soc Behav Sci 48:2876-2886

96. Yannis G, Dragomanovits A, Laiou A, La Torre F, Domenichini L, Richter T, Ruhl S, Graham D, Karathodorou N (2017) Road traffic accident prediction modelling: a literature review. Proc Inst Civ Eng Transp 170:245-254 
97. Young J, Park PY (2013) Benefits of small municipalities using jurisdictionspecific safety performance functions rather than the highway safety Manual's calibrated or uncalibrated safety performance functions. Can J Civ Eng 40:517-527

98. Zhong L, Sun $X$, He Y, Zhong $X$, Chen $Y$ (2009) Safety performance function for freeways in China. In: Paper presented at the 88th Transportation Research Board Annual Meeting, Washington, DC

Submit your manuscript to a SpringerOpen ${ }^{\circ}$ journal and benefit from:

- Convenient online submission

- Rigorous peer review

- Open access: articles freely available online

High visibility within the field

- Retaining the copyright to your article

Submit your next manuscript at $\boldsymbol{\sim}$ springeropen.com 